論 文

Original Paper

\title{
デジタルマイクロ天科による鉛蓄電池充放電反応のその場測定 *
}

\author{
田口正 美 1 \\ 田中順 朗 ${ }^{2}$ \\ 高 橋 \\ 悟 ${ }^{2}$ \\ 平 沢 今 吉 $^{3}$
}

\section{In-Situ Measurement on Charge-Discharge Reaction of Lead Acid Battery Using Digital Microbalance}

\author{
by Masami TAGUCHI ${ }^{\mathrm{a}}$, Satoru TAKAHASHI ${ }^{\mathrm{b}}$, Junro TANAKA ${ }^{\mathrm{b}}$ and Tokiyoshi HIRASAWA ${ }^{\mathrm{c}}$
}

a. Department of Materials Science and Engineering, Faculty of Engineering and Resource Science, Akita University, 1-1 Tegata Gakuenmachi, Akita 010-8502, Japan

(Corresponding author E-mail: taguchi@ipc.akita-u.ac.jp)

b. Graduate student, Akita University

c. Advanced Battery Technology Laboratory, Shin-Kobe Electric Machinery Co., Ltd., 2200 Oka Okabemachi, Saitama 369-0297, Japan

\begin{abstract}
Many electrode reactions have the mass change in addition to the charge transfer. In this study, a peculiar system was built and tested using a digital microbalance with the sensitivity of $10^{-5} \mathrm{~g}$ in order to measure insitu the mass change of the active materials in a lead-acid battery during charge-discharge reaction. On close inspection by the $\mathrm{Cu}$ electrodeposition, the mass change in-site measured by the system, which was corrected on account of the buoyancy of the electrolyte to the electrode, was good agreement with the value obtained by the exsitu measurement before and after the test. On the other hand, the higher the current density during electrolytic oxidation of $\mathrm{Pb}$, the smaller the production rate of $\mathrm{PbSO}_{4}$ and the larger that of $\mathrm{PbO}_{2}$. High concentration of $\mathrm{H}_{2} \mathrm{SO}_{4}$ also brought larger amount of $\mathrm{PbO}_{2}$ for all the same quantity of electricity. Moreover, a part of the discharge product $\mathrm{PbSO}_{4}$ could not returned to the $\mathrm{PbO}_{2}$ during charge-discharge cycling, as the cycling proceeded. The difference of the electrode mass was eventually observed between the start of the cycling and the finish of the $3^{\text {rd }}$ charging. The in-situ measurement also revealed that the reaction of $\mathrm{PbSO}_{4}$ to $\mathrm{Pb}$ and that of $\mathrm{Pb}$ to $\mathrm{PbSO}_{4}$ could start in the latter half of discharging and at the beginning of charging respectively.
\end{abstract}

KEY WORDS: Lead-Acid Battery, Mass Change, In-Situ Measurement, Lead Dioxide, Charge-Discharge

1. はじめに

鉛蓄電池の最大の用途は自動車用電源であるが ${ }^{1)}$, 自動車が高 度に電子制御化され，様々な快適装備を搭載するようになった今 日, 鉛蓄電池に対する大電流・大容量・長寿命化の要求はより一 層強いものになっている。また, 鉛蓄電池は, 電力負荷平準化の ための電力貯蔵システムや, 太陽光や風力等に代表されるクリー ンエネルギーでの変動電力の供給調整など, 新たな領域一の応用 もなされている2）。このよな状況下，ユーザーからの厳しい要 求に応えるためには, 次に示す電極反応について, 根本的で詳細 な解析を進めていくことが重要であろう。

$$
\begin{array}{r}
\text { 負極: } \mathrm{Pb}+\mathrm{H}_{2} \mathrm{SO}_{4}+2 \mathrm{H}_{2} \mathrm{O} \underset{\text { 充電 }}{\stackrel{\text { 放霄 }}{\rightleftarrows}} \\
\mathrm{PbSO}_{4}+2 \mathrm{H}_{3} \mathrm{O}^{+}+2 \mathrm{e}^{-} \cdot \cdots
\end{array}
$$

\footnotetext{
*2007 年 4 月 11 日受付 2008 年 1 月 31 日受理

1. 普通会員 秋田大学 工学資源学部 材料工学科 教授

2. 秋田大学大学院生

3. 新神戸電機 (株) 電池技術開発センター 所長

[ 著者連絡先 ] FAX: 018-889-2412( 秋田大・田口)

E-mail: taguchi@ipc.akita-u.ac.jp

キーワード : 鈆蓄電池, 質量変化, その場測定，二酸化鉛，充電 - 放電
}

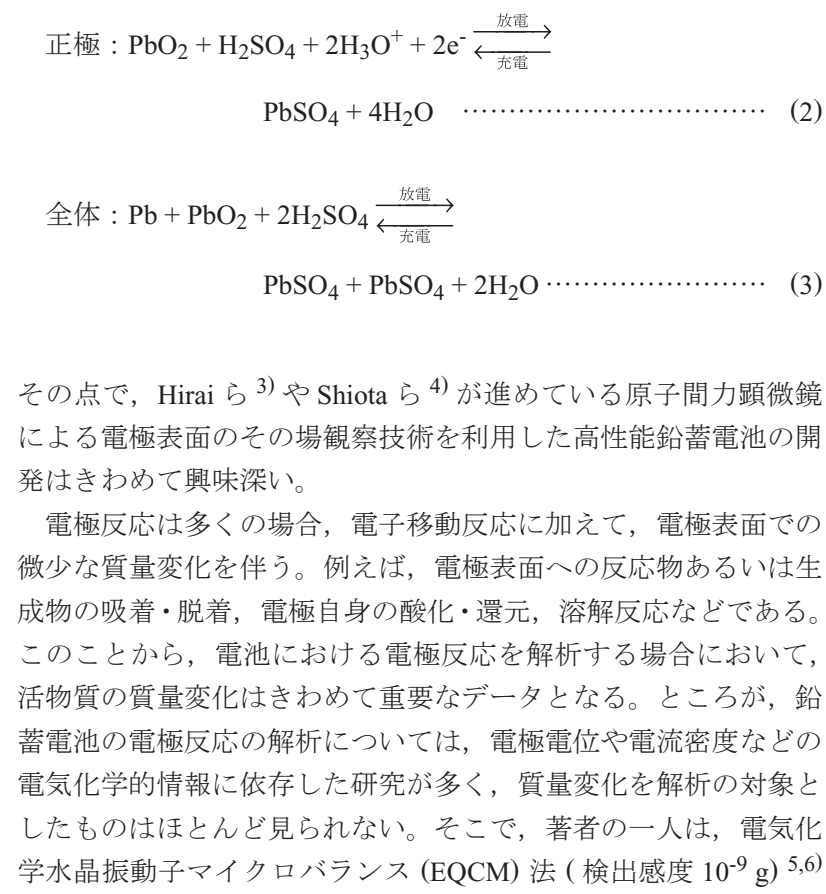

その点で, Hirai $5^{3)}$ やShiota $5^{4)}$ が進めている原子間力顕微鏡 による電極表面のその場観察技術を利用した高性能鉛蓄電池の開 発はきわめて興味深い。

電極反応は多くの場合, 電子移動反応に加えて, 電極表面での 微少な質量変化を伴う。例えば, 電極表面への反応物あるいは生 成物の吸着・脱着, 電極自身の酸化・還元, 溶解反応などである。 このことから, 電池における電極反応を解析寸る場合において, 活物質の質量変化はきわめて重要なデータとなる。ところが, 鈆 蓄電池の電極反応の解析については, 電極電位や電流密度などの 電気化学的情報に依存した研究が多く, 質量変化を解析の対象之 したものはほとんど見られない。そこで, 著者の一人は, 電気化 学水晶振動子マイクロバランス (EQCM) 法 (検出感度 $\left.10^{-9} \mathrm{~g}\right)^{5,6}$ ) 


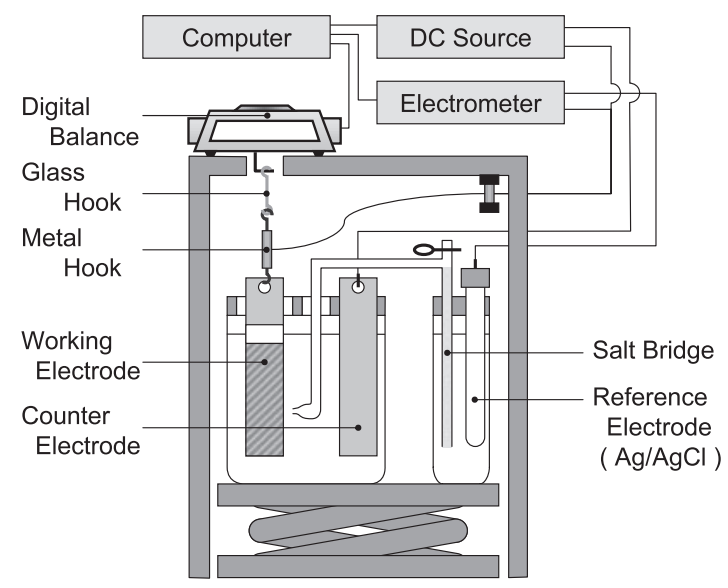

Fig.1 Apparatus for in-situ measurement of mass change during electrode reaction.

を用いて鈆蓄電池活物質の充放電過程における質量変動のその場 測定を試みた。その結果, 鉛蓄電池の充放電容量が負極活物質 $\mathrm{Pb}$ よりも正極活物質 $\mathrm{PbO}_{2}$ の充放電可逆性に強く依存することな ど, 鉛蓄電池の電極活物質の反応特性や電池の高出力・長寿命化 に関する幾つかの有益な知見を得ることができた ${ }^{7-9) 。 し か し な ~}$ がら，この方法では，測定できる質量変化量に制限があるため， 鉛蓄電池活物質の充放電挙動を全体的に把握することは困難であ った。

本研究では, 以上をふまえ, 鉛蓄電池活物質, 特に正極活物質 $\mathrm{PbO}_{2}$ の充放電時の質量変化を検出感度 $10^{-5} \mathrm{~g}$ のデジタルマイク 口天秤にてその場測定し, 電極反応を部分的ではなく全体的に把 握することを考えた。すなわち，(1) 床下秤量機能を有するデジ タルマイクロ天秤を用いた質量変化のその場測定システムを構築 し, (2) 純 $\mathrm{Pb}$ 板を試料電極として, 電解酸化によりその表層を $\mathrm{PbO}_{2}$ に化成処理する際の質量変化を計測した。さらに, (3) 得ら れた $\mathrm{PbO}_{2} / \mathrm{Pb}$ 電極を用い, 質量変動のその場測定により鉛蓄電池 の正極活物質 $\mathrm{PbO}_{2}$ の充放電反応を調查した。ここでは, その場 測定データの検証はもとより, $\mathrm{Pb}$ の電解酸化ならびに $\mathrm{PbO}_{2}$ の充 放電反応に伴う質量変化をデジタルマイクロ天秤で初めてその場 測定できたので，報告する。

\section{2. 実 験 方 法}

\section{$2 \cdot 1$ 質量変化のその場測定}

定電流電解における試料電極の質量変化をその場測定するため に, Fig. 1 のよう実験システムを構築した。システムは, 電解 セル, プログラマブル直流電圧/電流電源 (ADVANTEST, R6145), エレクトロメータ (ADVANTEST, R8240), デジタルマ イクロ天秤 (METTLER TOLEDO, AG245, 検出感度 $10^{-5} \mathrm{~g}$ ) およ びパーソナルコンピュータ（DELL, DIMENSION XPS H266）より 成る。直流電圧 / 電流電源, エレクトロメータおよびコンピュー タはGP-IB インターフェイスを介して, デジタル天秤とコンピ ユータはRS232C インターフェイスを介して接続した。

定電流電解実験は，HP 社の VEE Ver. 5.01 で作成した制御プロ グラムを用いて，以下のように実施した。(1) 試料電極を金属フ ックに装着し, 絶縁性のガラスフックを介して, デジタル天秤下 部の床下秤量用フックに懸垂する。金属フックに装着したリード 線を, 直流電圧/電流電源およびエレクトロメータに接続する。 (2) 電解セルに電解液を満たす。対極 $\left(\mathrm{Pt}\right.$ 板, $\left.2.0 \mathrm{~cm}^{2}\right)$ および参照 電極 $\left(\mathrm{Ag} / \mathrm{AgCl}\right.$ 電極, 内部液 $\left.3.33 \mathrm{kmol} \mathrm{m}^{-3} \mathrm{KCl}\right)$ を直流電圧/電流
電源ならびにエレクトロメータに接続する。(3) コンピュータを 作動させ, デジタル天秤で計測される試料電極の質量を記録する。 (4) ジャッキにて電解セルを静かに上昇させ, 試料電極を電解液 に浸漬する。ルギン管 ( 先端内径 $0.7 \sim 0.8 \mathrm{~mm}$, 試料電極との距 離 $1 \mathrm{~mm}$ 程度 ) への電解液の吸い上げを行い, 試料電極 - 参照電 極間を電気的に短絡させる。(5) 所定の電解条件にて電解を行う。 エレクトロメータにより試料電極の電極電位を計測し, 印加電流 とともにコンピュータに記録する。

\section{$2 \cdot 2 \mathrm{Cu}$ 電析によるその場測定データの検証}

前述の実験システムで計測される質量変化の信頼性を検証する ため, エメリー紙で研磨した後エタノールで洗浄した $\mathrm{Cu}$ 板 (二 ラコ, 純度 99.96 mass \%, 表面積 $22.5 \mathrm{~cm}^{2}$ ) を試料電極として, $\mathrm{Cu}$ 電析試験を実施した。すなわち, $\left(2.0 \mathrm{kmol} \mathrm{m}^{-3} \mathrm{CuSO}_{4}+0.5\right.$ $\left.\mathrm{kmol} \mathrm{m}^{-3} \mathrm{H}_{2} \mathrm{SO}_{4}+1.0 \mathrm{kmol} \mathrm{m}^{-3} \mathrm{C}_{2} \mathrm{H}_{5} \mathrm{OH}\right)$ 混合溶液中にて, 印加電 流 $0.150,0.225$ および $0.300 \mathrm{~A}$ で $1.2 \mathrm{ks}$ の $\mathrm{Cu}$ 電析試験を行い, (1) 試験前後での試料電極の質量変化量から, Faraday の法則に基 づて電流効率を算出した。そして, (2) Cu 電析試験中, その場 測定された試料電極の質量変化ならびに(3) 電解液から試料電極 への浮力の影響を考慮して測定データを補正した值からそれぞれ 電流効率を算出し, (1) の結果と比較検討した。なお, 浮力補正 には電解液の比重データが必要であり, 比重瓶( ゲー・リュサッ ク型 $25 \mathrm{~cm}^{3}$ )を用いてこれを測定した。

\section{$2 \cdot 3 \mathrm{~Pb}$ の電解酸化}

$\mathrm{Pb}$ の電解酸化に及ぼす電流密度ならびに $\mathrm{H}_{2} \mathrm{SO}_{4}$ 濃度の影響を 調査した。試料電極である $\mathrm{Pb}$ 板 (DOWA, 純度 99.99 mass $\%$, 表 面積 $15.08 \mathrm{~cm}^{2}$ ) は, アセトン中で超音波洗浄した後，(䣷酸 +30 \%過酸化水素水) 混合溶液 (体積比 $3: 1$ ) で $5 \mathrm{~s}$ エッチングした。 その後, (1) 電流密度の影響を調べるために, 浴温 $298 \mathrm{~K}$, 濃度 $0.5 \mathrm{kmol} \mathrm{m}^{-3}$ の $\mathrm{H}_{2} \mathrm{SO}_{4}$ 溶液中において電流密度を $2.5,5.0,10.0$ および $15.0 \mathrm{~mA} \mathrm{~cm}{ }^{-2}$ に変化させて時間 $3.6 \mathrm{ks}$ の電解酸化を行い, その場測定システムにより試料電極の電位と質量変化を計測し た。さらに, (2) $\mathrm{H}_{2} \mathrm{SO}_{4}$ 濃度の影響を確認するために, 電流密度 を $15.0 \mathrm{~mA} \mathrm{~cm}{ }^{-2}$ 一定として, 濃度 $0.1,0.5,1.0$ および $5.0 \mathrm{kmol}$ $\mathrm{m}^{-3}$ の $\mathrm{H}_{2} \mathrm{SO}_{4}$ 溶液中で, (1) と同様の試験を行った。電解酸化し た試料電極の表面生成物については, X 線回折 (日本電子, JDX-3530, Cu 管球, 管電圧 $40 \mathrm{kV}$, 管電流 $40 \mathrm{~mA}$ ) による化合物 の同定を行うとともに, 電界放射型走查電子顕微鏡 (FE-SEM, 日立ハイテク, S-4500)により微細組織を観察した。

\section{$2 \cdot 4 \mathrm{PbO}_{2}$ の放電試験}

$\mathrm{H}_{2} \mathrm{SO}_{4}$ 濃度を $0.1 ， 0.5,1.0$ および $5.0 \mathrm{kmol} \mathrm{m}^{-3}$ に変化させた 浴温 $298 \mathrm{~K}$ の $\mathrm{H}_{2} \mathrm{SO}_{4}$ 溶液中, 電流密度 $15.0 \mathrm{~mA} \mathrm{~cm}$ - 2 で $3.6 \mathrm{ks}$ 電 解酸化して得た $\mathrm{PbO}_{2} / \mathrm{Pb}$ 電極について, 鉛蓄電池の正極活物質 $\mathrm{PbO}_{2}$ の放電試験を実施した。すなわち, 純 $\mathrm{Pb}$ 板を負極として, 浴温 $298 \mathrm{~K}$, 濃度 $4.5 \mathrm{kmol} \mathrm{m}^{-3}$ の $\mathrm{H}_{2} \mathrm{SO}_{4}$ 中, 電流密度 $1.0 \mathrm{~mA}$ $\mathrm{cm}^{-2}$ で時間 $3.6 \mathrm{ks}$ 放電し, 試料電極の電位と質量変化をその場測 定した。さらに, 濃度 $5.0 \mathrm{kmol} \mathrm{m}^{-3}$ の $\mathrm{H}_{2} \mathrm{SO}_{4}$ 溶液中, 電流密度 $5.0 \mathrm{~mA} \mathrm{~cm}$-2 で時間 $3.6 \mathrm{ks}$ 電解酸化して得た $\mathrm{PbO}_{2} / \mathrm{Pb}$ 電極に関し ては, 放電/充電サイクル試験を行った。このサイクル試験では, 電流密度 $1.0 \mathrm{~mA} \mathrm{~cm}{ }^{-2}$ で時間 $0.6 \mathrm{ks}$ 放電した後, 電流密度 $5.0 \mathrm{~mA}$ $\mathrm{cm}^{-2}$ で時間 $0.6 \mathrm{ks}$ 充電するという操作を 3 サイクル繰返した。ま た, 放電ならびに充電過程での $\mathrm{PbO}_{2} / \mathrm{Pb}$ 電極の微細組織の変化を, 前述の FE-SEM を用いて詳細に調査した。

\section{3. 実験結果と考察}

\section{$3 \cdot 1 \mathrm{Cu}$ 電析によるその場測定データの検証}

Fig. 2 には, 電流 $0.225 \mathrm{~A}$ で時間 $1.2 \mathrm{ks}$ の $\mathrm{Cu}$ 電析実験を行った 


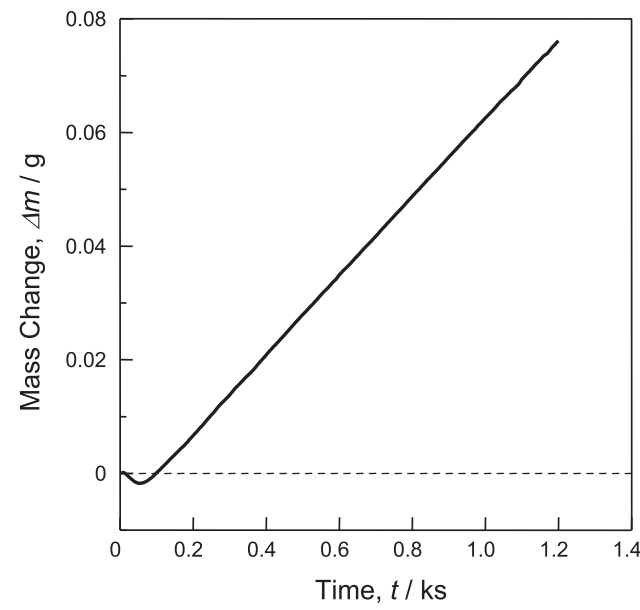

Fig.2 Change in mass of $\mathrm{Cu}$ electrode as a function of time during copper electrodeposition of $0.225 \mathrm{~A}$ for $1.2 \mathrm{ks}$ in $\left(2.0 \mathrm{kmol} \mathrm{m}^{-3} \mathrm{CuSO}_{4}+0.5 \mathrm{kmol} \mathrm{m}^{-3} \mathrm{H}_{2} \mathrm{SO}_{4}+1.0\right.$ $\left.\mathrm{kmol} \mathrm{m}{ }^{-3} \mathrm{C}_{2} \mathrm{H}_{5} \mathrm{OH}\right)$ solution at $298 \mathrm{~K}$

際に, デジタル天秤によってその場測定された $\mathrm{Cu}$ 電極の質量変 化 $\Delta m$ を示す。 $\mathrm{Cu}$ 電極の質量は実験開始直後から時間 $0.05 \mathrm{ks}$ 付 近まで僅かに減少するが，その後は電析時間の経過とともに直線 的に増大した。また, 印加電流を $0.150,0.225$ および $0.300 \mathrm{~A}$ に 増大させると, 直線の傾きつまり質量増加速度が上昇することを 確認した。ここで, 初期に $\mathrm{Cu}$ 電極の質量が減少した原因としては, 表層に存在する $\mathrm{Cu}_{2} \mathrm{O}$ などの酸化物層の還元や, 電流印加によっ てメニスカスが変化したことなどが考えられるが，現段階では特 定できていない。しかし, 実験中 $\mathrm{Cu}$ 電極からは気体発生などは 観察されなかったことから，その後は主として(4) 式で示される $\mathrm{Cu}$ 電析反応が進行したと判断された。

$$
\mathrm{Cu}^{2+}+2 \mathrm{e}^{-} \rightarrow \mathrm{Cu} \cdot
$$

そこで，通過電気量とIn-situ 測定すなわち Fig. 2 に示されたその 場測定データ $\Delta m$ から $\mathrm{Cu}$ 電析反応の電流効率を算出すると, $85.60 \%$ という值が得られた。ところが，Ex-situ測定すなわち $\mathrm{Cu}$ 電析前後において大気中で $\mathrm{Cu}$ 電極の質量を計測して得た質量变 化から算出される電流効率は $98.69 \%$ となった。このように, In$s i t u$ 測定の質量変化は Ex-situ 測定のそれに比較して小さいが，そ の原因としては, 電解液から Cu電極一の浮力の影響が考えられた。 そこで, 本研究では, (5) 式にてその場測定データ $\Delta m$ の浮力補正 を行い, 補正值 $\Delta m^{\prime}$ による電流効率の再計算を行うことにした。

$$
\Delta m^{\prime}=\Delta m+\frac{\Delta m \times \rho_{\text {electrolyte }}}{\rho_{\mathrm{Cu}}}
$$

ここで, $\rho_{\mathrm{Cu}}$ と $\rho_{\text {electrolyte }}$ はそれぞれ $\mathrm{Cu}$ 電極の比重 $\left.8.93 \mathrm{~g} \mathrm{~cm}^{-3} 10\right)$ および電解液の比重 $1.14 \mathrm{~g} \mathrm{~cm}^{-3}$ である。再計算の結果, 補正值 $\Delta m$, による電流効率は $98.20 \%$ となり, Ex-situ 測定の質量変化から算 出した電流効率と誤差 $0.5 \%$ 以内で一致した。したがって, 電解液 から試料電極への浮力を補正できるならば, 電極反応に伴う質量 変化のその場測定データはきわめて信頼性が高いと結論できる。

\section{$3 \cdot 2 \mathrm{PbO}_{2}$ 生成に及ぼす電流密度と硫酸濃度の影響}

これまでの $\mathrm{EQCM}$ 法による研究 7) から，鉛蓄電池における $\mathrm{PbSO}_{4} / \mathrm{Pb}$ 電極の酸化・還元反応の進展には電流密度が大きく影 響することが知られている。また, 硫酸水溶液中で生成する $\mathrm{PbSO}_{4}$ の形状や粒径が硫酸濃度によって著しく変化することは周 知の事実であり ${ }^{1)}$, 正極活物質 $\mathrm{PbO}_{2}$ に関しても同様のことが予

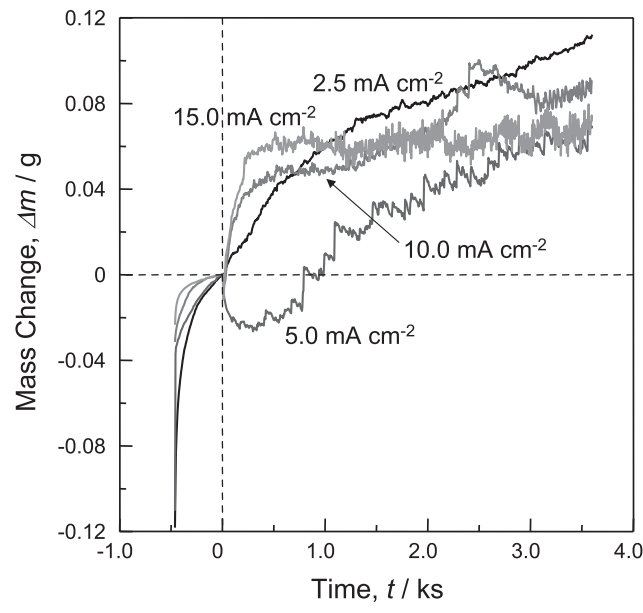

Fig.3 Change in mass of $\mathrm{Pb}$ electrode during electrolytic oxidation at various current densities ranging from 2.5 to $15.0 \mathrm{~mA} \mathrm{~cm}^{-2}$ in $0.5 \mathrm{kmol} \mathrm{m}^{-3} \mathrm{H}_{2} \mathrm{SO}_{4}$ at $298 \mathrm{~K}$.
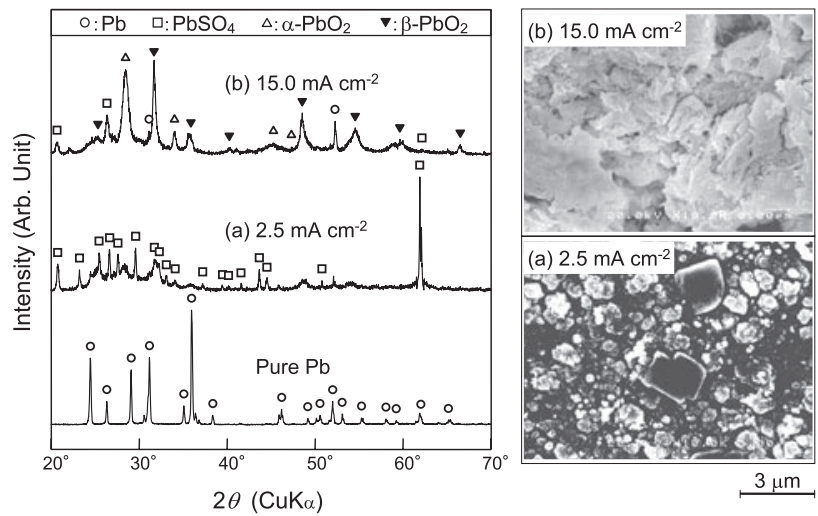

Fig.4 XRD patterns and SEM images for $\mathrm{Pb}$ electrodes after electrolytic oxidation of (a) 2.5 and (b) $15.0 \mathrm{~mA} \mathrm{~cm}$-2 for $3.6 \mathrm{ks}$ in $0.5 \mathrm{kmol} \mathrm{m}^{-3}$ $\mathrm{H}_{2} \mathrm{SO}_{4}$ at $298 \mathrm{~K}$.

想された。そこで, 電解酸化による $\mathrm{PbO}_{2}$ 生成に関して, 初めに 電流密度と硫酸濃度の影響を調査することにした。

Fig. 3 は, 浴温 $298 \mathrm{~K}$, 濃度 $0.5 \mathrm{kmol} \mathrm{m}^{-3}$ の $\mathrm{H}_{2} \mathrm{SO}_{4}$ 中, $2.5 \sim$ $15.0 \mathrm{~mA} \mathrm{~cm}^{-2}$ の各電流密度で電解酸化を行った際に, デジタル天 秤によってその場測定された $\mathrm{Pb}$ 電極の質量変化 $\Delta m$ を示す。電 流密度 $2.5 \mathrm{~mA} \mathrm{~cm}^{-2}$ では, $\mathrm{Pb}$ 電極の質量は連続的に上昇し, 時間 $3.6 \mathrm{ks}$ での質量増加量は $0.10 \mathrm{~g}$ を超えた。電流密度 $5.0 \mathrm{~mA} \mathrm{~cm}-2$ では, 一旦減少した質量が $0.3 \mathrm{ks}$ 経過した付近から増加に転じ, その後も連続的に上昇した。また, 電流密度 $10.0 \mathrm{~mA} \mathrm{~cm}{ }^{-2}$ では, 質量は電解初期に急増寸るものの, 時間 $3 \mathrm{ks}$ 付近からその増加 量は小さくなった。さらに, 電流密度 $15.0 \mathrm{~mA} \mathrm{~cm}{ }^{-2}$ になると, 初期の質量増加はより著しくなるが, その後は $0.06 \mathrm{~g}$ 程度で一定 になった。

Fig. 4 には，電流密度 (a) 2.5 ならびに (b) $15.0 \mathrm{~mA} \mathrm{~cm}{ }^{-2}$ で $3.6 \mathrm{ks}$ 電解酸化した $\mathrm{Pb}$ 電極表面の XRD パターンと二次電子像を示す。 電流密度 $2.5 \mathrm{~mA} \mathrm{~cm}{ }^{-2}$ で電解酸化した $\mathrm{Pb}$ 電極表面は大小さまざ まなブロック状の生成物に覆われており, XRD 分析よりそれら は斜方晶系 $\mathrm{PbSO}_{4}$ と同定された。一方, 電流密度 $15.0 \mathrm{~mA} \mathrm{~cm}$ では, $\mathrm{Pb}$ 電極表面は厚い繊維状の生成物によって覆われており, それらは斜方晶系 $\alpha-\mathrm{PbO}_{2}$ と正方晶系 $\beta-\mathrm{PbO}_{2}$ の混合組織と判断 された。

ここで, 電解酸化での $\mathrm{PbO}_{2}$ 生成に及ぼす電流密度と硫酸濃度 


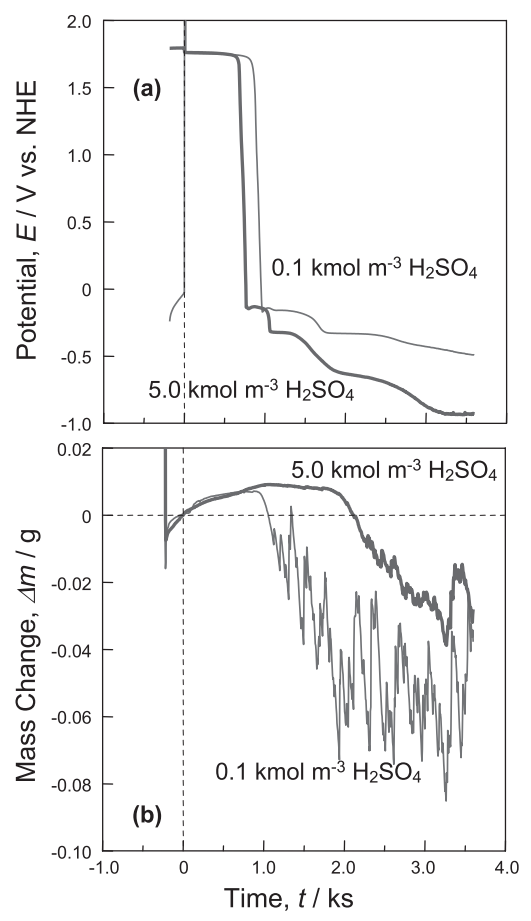

Fig.5 Changes in (a) potential and (b) mass of $\mathrm{PbO}_{2} / \mathrm{Pb}$ electrode during discharge of $1.0 \mathrm{~mA} \mathrm{~cm}^{-2}$ in $4.5 \mathrm{kmol} \mathrm{m}^{-3}$ $\mathrm{H}_{2} \mathrm{SO}_{4}$ at $298 \mathrm{~K}$. The $\mathrm{PbO}_{2} / \mathrm{Pb}$ electrodes were prepared by electrolytic oxidation of $\mathrm{Pb}$ at $15.0 \mathrm{~mA} \mathrm{~cm}{ }^{-2}$ for $3.6 \mathrm{ks}$ in 0.1 and $5.0 \mathrm{kmol} \mathrm{m}^{-3} \mathrm{H}_{2} \mathrm{SO}_{4}$ at $298 \mathrm{~K}$ respectively.

の影響をまとめると, 濃度 $0.5 \mathrm{kmol} \mathrm{m}^{-3}$ の $\mathrm{H}_{2} \mathrm{SO}_{4}$ 中での電解酸 化では, 電流密度が上昇するほど $\mathrm{PbSO}_{4}$ の回折ピークが減衰し, 代わってより酸化数の大きな $\alpha-\mathrm{PbO}_{2}$ と $\beta-\mathrm{PbO}_{2}$ が支配的になる と言える。一方, 電流密度 $15.0 \mathrm{~mA} \mathrm{~cm}-2$ 一定の下, 濃度 0.1 $5.0 \mathrm{kmol} \mathrm{m}^{-3}$ の $\mathrm{H}_{2} \mathrm{SO}_{4}$ 溶液中で電解酸化した $\mathrm{Pb}$ 電極の $\mathrm{XRD}$ 分析 では, 高濃度硫酸中での $\mathrm{Pb}$ 電極ほど $\mathrm{PbSO}_{4}$ が減衰し, $\mathrm{PbO}_{2}$ が 生成し易いことが分かった。

ところで, Fig. 3 では, 電解酸化開始前 ( $0 \mathrm{~s}$ 以前) に既に質量 増加が認められる。これは, $\mathrm{Pb}$ 電極を $\mathrm{H}_{2} \mathrm{SO}_{4}$ 中に浸漬すると, 水素イオンが酸化剂となり, 表層に直ちに $\mathrm{PbSO}_{4}$ が析出するた めである7)。

$$
\mathrm{Pb}+2 \mathrm{H}^{+}+\mathrm{SO}_{4}^{2-} \rightarrow \mathrm{PbSO}_{4}+\mathrm{H}_{2}
$$

また, 析出した $\mathrm{PbSO}_{4}$ が $\mathrm{Pb}$ 電極における反応サイトを減少させ るため, 質量増加は時間に対して放物線則的に変化すると解釈で きる。一方, 電解酸化過程 $(0 \mathrm{~s}$ 以降 $)$ での質量変化は，以下のよ うに考察できる。 $2.5 \mathrm{~mA} \mathrm{~cm}-2$ 程度の低電流密度では, $\mathrm{PbO}_{2}$ への 酸化が進行し得るほどの高い電極電位に達しないため, 主として （6）式の反応が進行し，質量は連続的に上昇寸る。これに対し, 電流密度 $5.0 \mathrm{~mA} \mathrm{~cm}$-2 以上では, (7) 式で示される $\mathrm{PbSO}_{4} \rightarrow \mathrm{PbO}_{2}$ の酸化反応が生起し, $\Delta m$ に質量減少が重畳されたと考えること ができる 1,7$) 。$

$$
\mathrm{PbSO}_{4}+2 \mathrm{H}_{2} \mathrm{O} \rightarrow \mathrm{PbO}_{2}+4 \mathrm{H}^{+}+\mathrm{SO}_{4}{ }^{2-}+2 \mathrm{e}^{-}
$$

さらに, $15.0 \mathrm{~mA} \mathrm{~cm}{ }^{-2}$ で認められる $\Delta m$ の著しい振動は, 電解酸 化の副反応である $\mathrm{O}_{2}$ 発生反応によると推察される。

$\mathrm{H}_{2} \mathrm{O} \rightarrow 2 \mathrm{H}^{+}+1 / 2 \mathrm{O}_{2}+2 \mathrm{e}^{-}$

$3 \cdot 3$ 各濃度硫酸中で電解酸化して得た $\mathrm{PbO}_{2}$ の放電特性

Fig. 5 には, 濃度 0.1 あるいは $5.0 \mathrm{kmol} \mathrm{m}^{-3}$ の $\mathrm{H}_{2} \mathrm{SO}_{4}$ 中, 電流
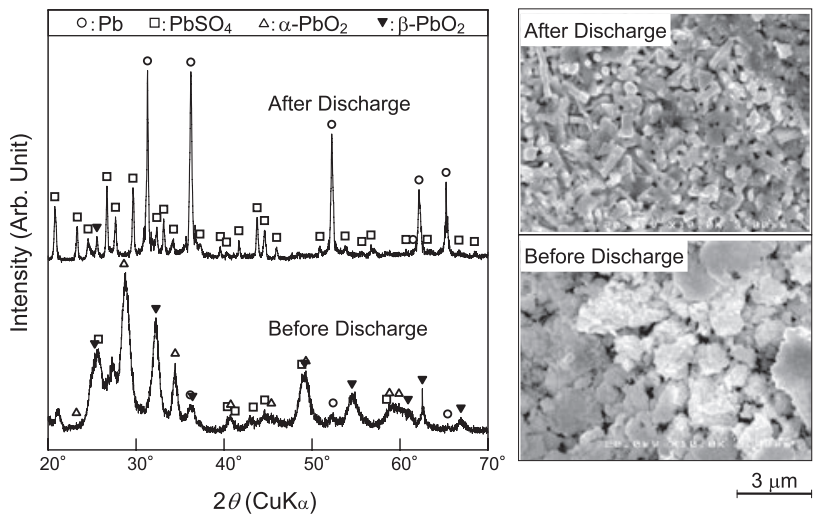

Fig.6 XRD patterns and SEM images for $\mathrm{PbO}_{2} / \mathrm{Pb}$ electrode before and after discharge of $1.0 \mathrm{~mA} \mathrm{~cm}^{-2}$ for $3.6 \mathrm{ks}$ in $4.5 \mathrm{kmol} \mathrm{m}^{-3} \mathrm{H}_{2} \mathrm{SO}_{4}$ at $298 \mathrm{~K}$. The $\mathrm{PbO}_{2} / \mathrm{Pb}$ electrode was prepared by electrolytic oxidation of $\mathrm{Pb}$ at 15.0 $\mathrm{mA} \mathrm{cm}{ }^{-2}$ for $3.6 \mathrm{ks}$ in $5.0 \mathrm{kmol} \mathrm{m}^{-3} \mathrm{H}_{2} \mathrm{SO}_{4}$ at $298 \mathrm{~K}$.

密度 $15.0 \mathrm{~mA} \mathrm{~cm}$-2 で時間 $3.6 \mathrm{ks}$ 電解酸化して得た $\mathrm{PbO}_{2} / \mathrm{Pb}$ 電極を, $4.5 \mathrm{kmol} \mathrm{m}^{-3}$ の $\mathrm{H}_{2} \mathrm{SO}_{4}$ 中, 電流密度 $1.0 \mathrm{~mA} \mathrm{~cm}{ }^{-2}$ で放電した際の (a) 電極電位 $E$ および (b) 質量変化 $\Delta m$ を示す。電池活物質の放電 挙動に関して, 電位データは数多くの論文に取り上げられている が，質量変化のその場測定データを採用した研究はほとんど例が ない。なお，放電電流を $1.0 \mathrm{~mA} \mathrm{~cm}{ }^{-2}$ に設定したのは，緩やかな 放電反応を生起させ, 質量変化 $\Delta m$ をより正確に測定する狙いが あった。濃度 $0.1 \mathrm{kmol} \mathrm{m}^{-3}$ の $\mathrm{H}_{2} \mathrm{SO}_{4}$ 中の電解酸化で得た $\mathrm{PbO}_{2}$ では, 放電によって質量が放物線的に上昇して約 $0.007 \mathrm{~g}$ に達するが, 時間 $1.0 \mathrm{ks}$ 付近で急激に減少した。この時, $\mathrm{PbO}_{2}$ 表面からは気 泡が発生し始め, 質量変化 $\Delta m$ に激しい振動現象が現れた。一方, 濃度 $5.0 \mathrm{kmol} \mathrm{m}^{-3}$ の $\mathrm{H}_{2} \mathrm{SO}_{4}$ 中で得られた $\mathrm{PbO}_{2}$ の場合, 放電によ る質量増加は時間 $1.0 \mathrm{ks}$ 付近までであるが, 濃度 $0.1 \mathrm{kmol} \mathrm{m}^{-3}$ の $\mathrm{H}_{2} \mathrm{SO}_{4}$ 中で得られた $\mathrm{PbO}_{2}$ の場合とは異なり, その後も質量は低 下せず $\Delta m \doteqdot 0.008 \mathrm{~g}$ を維持した。そして, $2.0 \mathrm{ks}$ 付近で初めて質 量が低下寸ることが, その場測定により観察された。したがって, 共存する $\mathrm{PbSO}_{4}$ による影響もあるが, 濃度 $5.0 \mathrm{kmol} \mathrm{m}^{-3}$ の $\mathrm{H}_{2} \mathrm{SO}_{4}$ 中で生成した $\mathrm{PbO}_{2} / \mathrm{Pb}$ 電極の正極活物質としての容量は, 濃度 $0.1 \mathrm{kmol} \mathrm{m}^{-3}$ の $\mathrm{H}_{2} \mathrm{SO}_{4}$ 中同一電気量で調製した $\mathrm{PbO}_{2} / \mathrm{Pb}$ 電極の 2 倍程度になると判断できる。さらに, $\mathrm{PbO}_{2} / \mathrm{Pb}$ 電極を調製した電 解液の硫酸濃度と放電により質量が低下寸るまでの時間との関係 を調べると, $5.0>1.0 \fallingdotseq 0.5>0.1 \mathrm{kmol} \mathrm{m}^{-3}$ の順となり, 同一電気 量での $\mathrm{PbO}_{2} / \mathrm{Pb}$ 電極の調製では, 高濃度硫酸中の方が正極活物質 $\mathrm{PbO}_{2}$ の生成量が多いことが判明した。このような知見は，電位 データのみでは導き得ないものであり，質量変化のその場測定デ 一タとの併用で初めて得られる。本測定の優位性が発揮される典 型例と考えられる。

Fig. 6 には, 濃度 $5.0 \mathrm{kmol} \mathrm{m}^{-3}$ の $\mathrm{H}_{2} \mathrm{SO}_{4}$ 中で電解酸化して得ら れた $\mathrm{PbO}_{2} / \mathrm{Pb}$ 電極の放電前後の $\mathrm{XRD}$ パターンと二次電子像を示 す。 $\mathrm{XRD}$ 分析によれば, 放電前 $\alpha-\mathrm{PbO}_{2}$ と $\beta-\mathrm{PbO}_{2}$ が支配的であ った $\mathrm{PbO}_{2} / \mathrm{Pb}$ 電極が, 放電後には $\mathrm{PbSO}_{4}$ と $\mathrm{Pb}$ から成る組織に変 化していることが分かった。また, それに伴って, 二次電子像の 形態も厚い繊維状の組織から長さ $1 \mu \mathrm{m}$ 程度の短冊状のそれに大 きく変化した。これらの結果から, Fig. 5 の放電前半に認められ る質量増加は，(9) 式に従って $\mathrm{PbO}_{2}$ が $\mathrm{PbSO}_{4}$ に変化する過程を 反映していると考えられる1)。

$\mathrm{PbO}_{2}+4 \mathrm{H}^{+}+\mathrm{SO}_{4}{ }^{2-}+2 \mathrm{e}^{-} \rightarrow \mathrm{PbSO}_{4}+2 \mathrm{H}_{2} \mathrm{O}$ 

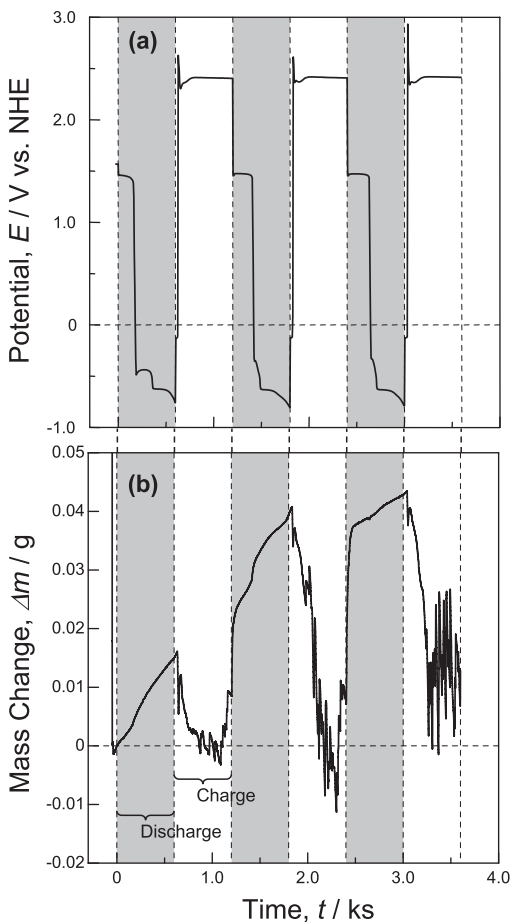

Fig.7 Changes in (a) potential and (b) mass of $\mathrm{PbO}_{2} / \mathrm{Pb}$ electrode during discharge-charge cycling in $4.5 \mathrm{kmol} \mathrm{m}^{-3} \mathrm{H}_{2} \mathrm{SO}_{4}$ at $298 \mathrm{~K}$. The $\mathrm{PbO}_{2} / \mathrm{Pb}$ electrode was prepared by electrolytic oxidation of $\mathrm{Pb}$ at $15.0 \mathrm{~mA} \mathrm{~cm}-2$ for $3.6 \mathrm{ks}$ in $5.0 \mathrm{kmol} \mathrm{m}^{-3} \mathrm{H}_{2} \mathrm{SO}_{4}$ at $298 \mathrm{~K}$ The current densities of discharge and charge were 1.0 and $5.0 \mathrm{~mA} \mathrm{~cm}^{-2}$ respectively.

$E=1.691-0.1182 \mathrm{pH}-0.0295 \mathrm{p}\left(\mathrm{SO}_{4}{ }^{2-}\right) \mathrm{V}$ vs. NHE

また, 放電後半の著しい質量減少とその後の振動は, $\mathrm{PbSO}_{4}$ か ら $\mathrm{Pb}$ 一の還元反応と $\mathrm{H}_{2}$ の発生反応に関係すると解釈できる ${ }^{7,11)}$

$\mathrm{PbSO}_{4}+\mathrm{H}^{+}+2 \mathrm{e}^{-} \rightarrow \mathrm{Pb}+\mathrm{HSO}_{4}^{-}$

$E=-0.302-0.0295 \mathrm{pH}+0.0295 \mathrm{p}\left(\mathrm{HSO}_{4}^{-}\right) \mathrm{V}$ vs. NHE

$2 \mathrm{H}^{+}+2 \mathrm{e}^{-} \rightarrow \mathrm{H}_{2}$

$E=-0.0591 \mathrm{pH}-0.0295 \mathrm{p}\left(\mathrm{H}_{2}\right) \mathrm{V}$ vs. NHE

$3 \cdot 4 \mathrm{PbO}_{2}$ の充放電サイクルにおける電位および質量変化

Fig. 7 には, 濃度 $5.0 \mathrm{kmol} \mathrm{m}^{-3}$ の $\mathrm{H}_{2} \mathrm{SO}_{4}$ 中で電解酸化して得ら れた $\mathrm{PbO}_{2} / \mathrm{Pb}$ 電極の放電/充電少イクル試験での (a) 電位 $E$ およ び (b) 質量変化 $\Delta m$ を示す。この試験は浴温 $298 \mathrm{~K}$, 濃度 $4.5 \mathrm{kmol}$ $\mathrm{m}^{-3}$ の $\mathrm{H}_{2} \mathrm{SO}_{4}$ 中で実施され，電流密度 $1.0 \mathrm{~mA} \mathrm{~cm}-2$ で時間 $0.6 \mathrm{ks}$ 放電した後電流密度 $5.0 \mathrm{~mA} \mathrm{~cm}{ }^{-2}$ で時間 $0.6 \mathrm{ks}$ 充電する操作を 3 サイクル繰返した。

第 1 サイクルの放電では, $\mathrm{PbO}_{2} / \mathrm{Pb}$ 電極の質量は連続的に上昇 し, $\Delta m$ は $0.6 \mathrm{ks}$ で約 $0.015 \mathrm{~g}$ となった。この間, 初めは $1.44 \mathrm{~V}$ vs. NHE であった $\mathrm{PbO}_{2} / \mathrm{Pb}$ 電極の電位が，時間 $0.14 \mathrm{ks}$ 付近にお いてー $0.5 \mathrm{~V}$ vs. NHEまで瞬時に低下した。その後，電位は時間 $0.37 \mathrm{ks}$ で- $0.70 \mathrm{~V}$ vs. NHE まで低下し, 時間 $0.50 \mathrm{ks}$ 以降にも更に 低下寸る傾向を示した。ところが, 充電状態に切替えると, 電位 は数秒で- $0.13 \mathrm{~V}$ vs. NHE 程度になり, 一旦停滞した後に $2.5 \mathrm{~V}$ vs. NHE 付近まで上昇した。そして, $\mathrm{PbO}_{2} / \mathrm{Pb}$ 電極の質量は減少し,
$0.3 \mathrm{ks}$ ほどの時間で $\Delta m \fallingdotseq 0$ すなわち放電前の質量に戻った。こ のような挙動は, 基本的には第 2 あるいは第 3 サイクルの放電な らびに充電過程でも認められる。しかし，第 3 サイクルの充電過 程では, 質量が完全には $\Delta m \fallingdotseq 0$ の状態には戻らないことから, 前段階で何らかの不可逆な反応が進行したことが伺われた ${ }^{9)}$

Fig. 8 には，第 1 サイクルの放電過程における $\mathrm{PbO}_{2} / \mathrm{Pb}$ 電極表 面の二次電子像を示す。肉眼による観察では, 図中(1)〜(3)の段階 において, 電極はいずれも茶褐色ないしは黒褐色であった。とこ ろが，二次電子像からは，放電前 ( (1) ) 綿状であった組織が放電

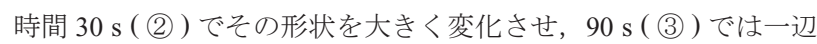
が $0.5 \sim 1 \mu \mathrm{m}$ のブロックに成長している様子が分かる。しかも, この際の電位が $1.42 \sim 1.46 \mathrm{~V}$ vs. NHEに保持されていることから, 電極表面上では (9) 式の $\mathrm{PbO}_{2} \rightarrow \mathrm{PbSO}_{4}$ の反応が進行したと推察 できる。また, 電位が $-0.5 \mathrm{~V}$ vs. NHEに低下するのに伴い, $\mathrm{PbO}_{2} / \mathrm{Pb}$ 電極の退色が急速に進行し, 放電開始後 $300 \mathrm{~s}$ ( (4) ) $600 \mathrm{~s}$ ( (5) ) ではグレーになることが, 肉眼で観察できた。さらに, この際の質量変化を見ると, 質量は連続的に増加しているが, $300 \mathrm{~s}$ 以降でその増加速度が鈍化しているのが分かる(破線参照)。 これは, 通常の $\mathrm{PbO}_{2} \rightarrow \mathrm{PbSO}_{4}$ の反応に加えて, (10) 式で示され る $\mathrm{PbSO}_{4}$ が $\mathrm{Pb}$ に還元される反応が生起したためと解釈できる。 したがって, $\mathrm{PbO}_{2}$ の放電過程では, 単に $\mathrm{PbSO}_{4}$ の生成反応にと どまらず，条件によっては $\mathrm{Pb}$ 一還元反応が進行すると言える。

さらに, Fig. 9 には, 第 1 サイクルの充電過程における $\mathrm{PbO}_{2} /$ $\mathrm{Pb}$ 電極表面の二次電子像を示す。肉眼による観察では, $\mathrm{PbO}_{2} / \mathrm{Pb}$ 電極の色彩は充電開始直後において黄色がかったグレーから黒褐 色に急変したが，その後はほとんど変わらないことが分かった。 この電極を FE-SEM で観察すると, 充電 $30 \mathrm{~s} \mathrm{(} \mathrm{(6)} \mathrm{)} \mathrm{まではブロッ}$ ク状態が維持されているが，300 s ( (7) ) では表層が微細な析出物 で覆われ，600 s（８）においてはそれらが成長した形態が確認さ れた。一方, 質量変化を見ると, これまで一般的に考えられてい たのとは異なり, 充電過程で直ちに質量減少が始まるわけではな いことが判明した。すなわち, 充電開始 $50 \mathrm{~s}$ 程度は質量増加が 継続し ( 矢印参照), その後に急激な質量減少が起こることが分 かった。充電初期のこの質量増加は，(10) 式の逆反応すなわち電 


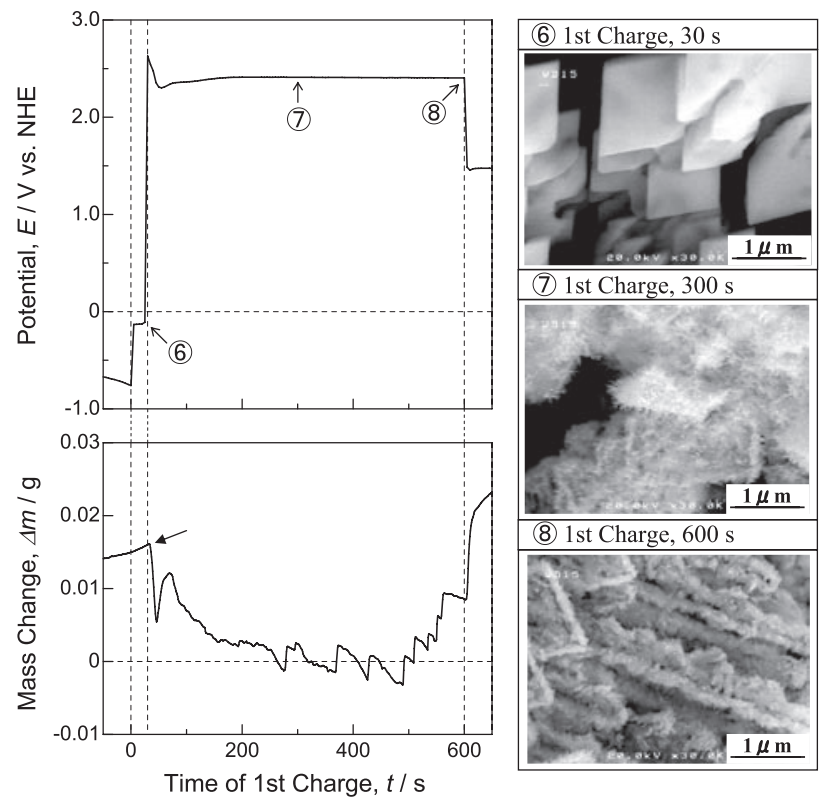

Fig.9 Changes in potential, mass and SEM image of $\mathrm{PbO}_{2} / \mathrm{Pb}$ electrode during $1^{\text {st }}$ charge in $4.5 \mathrm{kmol} \mathrm{m}^{-3} \mathrm{H}_{2} \mathrm{SO}_{4}$ at $298 \mathrm{~K}$. The current density of charge was $5.0 \mathrm{~mA} \mathrm{~cm}^{-2}$.

極中の $\mathrm{Pb}$ が $\mathrm{PbSO}_{4}$ に酸化される反応に起因すると解釈できる。 これは，この期間において電位が約 $-0.15 \mathrm{~V}$ vs. NHE に維持され ていることからも裏付けられる。そして，その後は，(9)式の逆 反応すなわち $\mathrm{PbSO}_{4} \rightarrow \mathrm{PbO}_{2}$ が主反応となるため, 質量は大きく 低下寸る。さらに, 反応開始 $300 \mathrm{~s}$ 以降で質量が上下に振動する 点に関しては, 電極表面の主反応が $\mathrm{PbO}_{2}$ の生成反応から (12) 式 の酸素発生反応に移行し, 発生ガスによるノイズが増大したため と推察できる。

$$
\begin{aligned}
& 2 \mathrm{H}_{2} \mathrm{O} \rightarrow \mathrm{O}_{2}+4 \mathrm{H}^{+}+4 \mathrm{e}^{-} \\
& E=1.228-0.0591 \mathrm{pH}-0.0148 \mathrm{p}\left(\mathrm{O}_{2}\right) \mathrm{V} \text { vs. NHE }
\end{aligned}
$$

以上のように, 本研究では, $\mathrm{PbO}_{2}$ の充放電過程での質量変化を デジタルマイクロ天秤により初めてその場測定し, 電極電位や電 流密度などの電気化学的情報だけでは知り得ない幾つかの事実を
確認した。これらの事実は, 今後鉛蓄電池の大電流・大容量化を 進める際にきわめて重要な知見になると期待される。

$$
\text { 4.おわりに }
$$

本研究では, 鉛蓄電池正極活物質 $\mathrm{PbO}_{2}$ の充放電に伴う質量変 化をその場測定するため, 検出感度 $10^{-5} \mathrm{~g}$ のデジタルマイクロ天 秤を用いた計測システムを構築した。得られた結果は, 以下のよ うに要約できる。

(1) 質量変化のその場測定データを $\mathrm{Cu}$ 電析試験により検証した ところ, 浮力補正を施した測定データは電解液中での電極反 応に伴う質量変化とほぼ正確に一致することが分かった。

(2) $\mathrm{Pb}$ の電解酸化では, 高電流密度で酸化した $\mathrm{Pb}$ 電極ほど $\mathrm{PbSO}_{4}$ の生成が少なくなり, $\mathrm{PbO}_{2}$ が生成し易いことが分かっ た。また, 同一電気量では, 高濃度 $\mathrm{H}_{2} \mathrm{SO}_{4}$ 中で電解酸化した 方が $\mathrm{PbO}_{2}$ の生成量が多いことを確認した。そのため, 濃度 $5.0 \mathrm{kmol} \mathrm{m}^{-3}$ の $\mathrm{H}_{2} \mathrm{SO}_{4}$ 中で生成した $\mathrm{PbO}_{2} / \mathrm{Pb}$ 電極の正極電池 活物質としての容量は, 濃度 $0.1 \mathrm{kmol} \mathrm{m}^{-3}$ の $\mathrm{H}_{2} \mathrm{SO}_{4}$ 中で調製 した $\mathrm{PbO}_{2} / \mathrm{Pb}$ 電極の 2 倍程度になった。

(3) $\mathrm{PbO}_{2}$ の放電/充電サイクル試験では, 電極電位と質量変化を その場測定できた。放電過程では, 主として $\mathrm{PbO}_{2} \rightarrow \mathrm{PbSO}_{4}$ が進行し質量の増大が観測された。充電過程では, その逆の 反応が生起し質量は減少するが, 3 サイクル目の充電では放 電生成物が完全には元の状態に戻らず，不可逆な放電生成物 が残存することが示唆された。また, $\mathrm{PbO}_{2} \leftrightarrows \mathrm{PbSO}_{4}$ の主反応 に加えて, 放電反応の後期には $\mathrm{PbSO}_{4} \rightarrow \mathrm{Pb}$ の反応が, 充電 反応の初期には $\mathrm{Pb} \rightarrow \mathrm{PbSO}_{4}$ の反応が重畳されることなど, 新たな事実を確認した。

\section{References}

1) Y. Matsuda, Z. Takehara : Denchi Binran $3^{\text {rd }}$ Edition, (Maruzen, 2001), p. 159, 180 2) T. Ohmae: Electrochemistry, 72 (2004), 652-655.

3) N. Hirai, K. Takeda, S. Hara, M. Shiota, Y. Yamaguchi and Y. Nakayama: J. Power Sources, 113 (2003), 329-334.

4) M. Shiota, Y. Yamaguchi, Y. Nakayama, K. Adachi, S. Taniguchi, N. Hirai and S. Hara: J. Power Sources, 95 (2001), 203-208.

5) N. Oyama, K. Naoi, T. Ohsaka: DENKI KAGAKU, 59 (1991), 937-942.

6) M. Seo : J. Surface Finishing Soc. Japan, 45 (1994), 1003-1008.

7) M. Taguchi and H. Sugita: J. Power Sources, 109 (2002), 294-300

8) M. Taguchi and H. Sugita: J. Japan Inst. Metals, 66 (2002), 670-675

9) M. Taguchi and K. Fukui: J. Japan Inst. Metals, 68 (2004), 887-893.

10) Japan Institute of Metals: Kinzoku Data Book, (Maruzen, 1974), p. 9.

11) P. Ruetschi: J. Electrochem. Soc., 120 (1973), 331-336. 